\title{
The expression of CCAAT/enhancer binding protein (C/EBP) in the human ovary in vivo: specific increase in C/EBP $\beta$ during epithelial tumour progression
}

\author{
K Sundfeldt' ${ }^{1}$ K Ivarsson², M Carlsson'1, S Enerbäck ${ }^{3}$, PO Janson², M Brännström² and L Hedin'1 \\ ${ }^{1}$ Department of Physiology, ${ }^{2}$ Department of Obstetrics and Gynaecology and ${ }^{3}$ Department of Molecular Biology, Göteborg University, Göteborg, Sweden
}

\begin{abstract}
Summary The CCAAT/enhancer binding protein (C/EBP) family of transcription factors is involved in metabolism and differentiation of cells, especially in rodent liver cells and adipocytes. Their roles in vivo and in particular during pathophysiological conditions in humans are largely unknown. We have investigated the presence of $\mathrm{C} / \mathrm{EBP} \alpha,-\beta,-\delta$ and $-\zeta$ in normal ovaries and in epithelial ovarian tumours of different stages. Immunohistochemical experiments demonstrated that C/EBP $\alpha$ and C/EBP $\beta$ were preferentially expressed in epithelial/tumour cells irrespective of stage or grade of the tumour. C/EBP $\beta$ was located in the nuclei of the cells, in contrast to $\mathrm{C} / \mathrm{EBP} \alpha$, which was present only in the cytoplasm of these cells. The nuclear localization of C/EBP $\beta$ indicates an active role of this transcription factor in tumour cells, whereas the cytoplasmic distribution suggests a more passive function of $\mathrm{C} / \mathrm{EBP} \alpha . \mathrm{C} / \mathrm{EBP} \delta$ and $-\zeta$ demonstrated a more diverse distribution with predominant localization to epithelial cells, but stromal distribution was also noted. The intracellular distribution was confined to both the nucleus and the cytoplasm for C/EBP $\delta$ and $-\zeta$. Western blotting demonstrated that C/EBP $\alpha,-\beta,-\delta$ and $-\zeta$ were present in a majority of the samples. The amount of C/EBP $\beta$ increased markedly with malignancy, i.e. with degree of dedifferentiation, while the other members of the C/EBP family displayed a more constant expression level. These results demonstrate an association between the expression of members of the C/EBP family and the formation of epithelial ovarian tumours, with C/EBP $\beta$ as a potential marker for these tumours. As C/EBP $\beta$ is known to be expressed during proliferation of cells in vitro, it may participate in the proliferative process of ovarian epithelial tumour cells in vivo and play a central role in tumour progression.
\end{abstract}

Keywords: ovarian surface epithelial cells; tumour formation; transcription factors; C/EBP

The CCAAT/enhancer binding protein $(\mathrm{C} / \mathrm{EBP})$ family of transcription factors is a group of six known proteins: $\mathrm{C} / \mathrm{EBP} \alpha$ (C/EBP), C/EBP $\beta$ (NF-IL6, LAP), C/EBP $\gamma$ (Ig-EBP), C/EBP $\delta$ (NF-IL6 $\beta$ ), C/EBPE (CRP-1) and C/EBP (CHOP, GADD153) (Vinson et al, 1993). These proteins consist of three domains: a DNA-binding domain, a regulatory domain and a dimerization domain. The dimerization domains of the different family members have a high degree of homology. This domain is a leucine-zipper motif that allows the C/EBP to dimerize as both homo- and heterodimers. They can also form heterodimers with other leucine-zipper proteins in the Fos/Jun family and the ATF/CREB family (Vinson et al, 1993). The DNA-binding regions of the dimerized proteins recognize a palindromic CCAAT motif in the promoter of target genes. However, heterodimerization of any of the family members with $\mathrm{C} / \mathrm{EBP} \zeta$ directs the complex away from this binding site because $\mathrm{C} / \mathrm{EBP} \zeta$ has a different DNAbinding domain (Ron and Habener, 1992). There are also shorter forms of $\mathrm{C} / \mathrm{EBP} \alpha$ and $-\beta$, which lack this DNA-binding domain. These truncated forms may also act as inhibitors of transcriptional activation (Descombes and Schibler, 1991; Lin et al, 1993).

The roles of the $\mathrm{C} / \mathrm{EBP}$ family in the control of proliferation and differentiation have mostly been studied in vitro in adipocytes

Received 17 November 1997

Revised 13 May 1998

Accepted 13 July 1998

Correspondence to: L Hedin, Department of Physiology, Göteborg University, PO Box 432, SE-405 30 Göteborg, Sweden
(Cao et al, 1991; Umek et al, 1991). These in vitro studies demonstrated that the $\beta$ - and $\delta$-forms were active during the proliferative stages in the transition of preadipocytes into adipocytes prior to the activation of $\mathrm{C} / \mathrm{EBP} \alpha$, which was expressed exclusively in the terminally differentiated cells. A constitutive expression of $\mathrm{C} / \mathrm{EBP} \alpha$ was also necessary to maintain adipocytes in their differentiated stage, when $\mathrm{C} / \mathrm{EBP} \alpha$ also acted as an antimitotic factor (McKnight, 1991; Samuelsson et al, 1991). C/EBPל has also the potential to act as an inhibitor of the transcription by blocking DNA binding of other C/EBPs through dimerization (Ron and Habener, 1992). This dimerization results in a reduction of the differentiation process in vitro (Batchvarova et al, 1995).

The C/EBP family is also involved in the differentiation process of other cell types, e.g. intestinal epithelium (Chandrasekaran and Gordon, 1993), ovarian follicles (Piontkewitz et al, 1993), type II alveolar cells of the lung (Li et al, 1995) and myeloid cells (Scott et al, 1992). The involvement of these transcription factors in human diseases is largely unknown, although a fusion protein containing $\mathrm{C} / \mathrm{EBP} \zeta$ has been reported in myxoid liposarcoma (Aman et al, 1992).

Ovarian tumours are the cause of $6 \%$ of deaths from malignancies in women in the Western hemisphere (Silverberg, 1984). Over $80 \%$ of these cancers originate from the surface (germinal) epithelium of the ovary (OSE cells). These carcinomas are suggested to originate from transformed OSE cells, either as a consequence of the repeated degradation and reconstitution of the ovarian surface after each ovulation or as the result of the formation of inclusion cysts with entrapped OSE cells (Hamilton, 1992). 
Table 1 List of tissues analysed for C/EBP $\alpha,-\beta,-\delta$ and $-\zeta$

\begin{tabular}{|c|c|c|c|c|c|c|c|}
\hline Sample no. & & Type & Stage & $\alpha$ & $\beta$ & $\delta$ & $\zeta$ \\
\hline N1 & $\mathrm{N}$ & Normal, fertile & & W & W & W & W \\
\hline N2 & $\mathrm{N}$ & Normal, fertile & & W & W & W & W \\
\hline N3 & $\mathrm{N}$ & Normal, fertile & & W & & W & W \\
\hline N4 & $\mathrm{N}$ & Normal, post-menopausal & & W & W & W & W \\
\hline N5 & $\mathrm{N}$ & Normal, post-menopausal & & 1 & I & I & 1 \\
\hline N6 & $\mathrm{N}$ & Normal, post-menopausal & & I & I & I & I \\
\hline N7 & $\mathrm{N}$ & Normal, post-menopausal & & 1 & I & 1 & I \\
\hline Tb1 & B & Adenoma & & 1 & 1 & 1 & 1 \\
\hline T8 & $\mathrm{B}$ & Adenofibroma & & W & W & W & W \\
\hline T12 & $\mathrm{B}$ & Adenofibroma & & W,I & W,I & W,I & W,I \\
\hline T17 & B & Adenoma & & W & W & & W \\
\hline T36 & $\mathrm{B}$ & Adenofibroma & & 1 & I & I & 1 \\
\hline T5 & $\mathrm{BL}$ & Borderline adenofibroma & IA & W & W & W & W \\
\hline T16 & $\mathrm{BL}$ & Borderline adenoma & IA & W,I & W,I & W,I & W,I \\
\hline T20 & $\mathrm{BL}$ & Borderline adenoma & IA & 1 & 1 & 1 & 1 \\
\hline T32 & $\mathrm{BL}$ & Borderline muc. adenoma & $\mathrm{IA}$ & I & I & I & I \\
\hline T22 & M & $\mathrm{h}$ diff. ser. adenocarcinoma & III & I & I & I & I \\
\hline T25 & M & h diff. ser. adenocarcinoma & III & I & I & 1 & I \\
\hline T34 & M & h diff. muc. adenocarcinoma & $\mathrm{IA}$ & I & 1 & 1 & I \\
\hline T9 & M & $\mathrm{m} / \mathrm{p}$ diff. ser. adenocarcinoma & III & W,I & W & W,I & W,I \\
\hline T15a & M & $\mathrm{m} / \mathrm{p}$ diff. ser. adenocarcinoma & III & W,I & I & 1 & W \\
\hline T15b & M & Metastasis t. $15 a$ & III & W & & W & W \\
\hline T29 & M & m diff. ser. adenocarcinoma & III & 1 & I & I & 1 \\
\hline T30 & M & m diff. ser. adenocarcinoma & III & I & I & I & I \\
\hline T31 & M & m diff. ser. adenocarcinoma & III & I & I & I & I \\
\hline T11 & M & $\mathrm{m} / \mathrm{p}$ diff. ser. adenocarcinoma & II & W & W & W & W \\
\hline T10a & M & $\mathrm{m} / \mathrm{p}$ diff. ser. adenocarcinoma & III & W & W & & W \\
\hline T10b & M & Metastasis t. $10 \mathrm{a}$ & III & W & W & & W \\
\hline T14 & M & $\mathrm{p}$ diff. ser. adenocarcinoma & III & W & W & W & W \\
\hline T26 & M & $\mathrm{p}$ diff. ser. adenocarcinoma & II & 1 & I & I & I \\
\hline T27 & M & $\mathrm{p}$ diff. ser. adenocarcinoma & IC & I & I & I & I \\
\hline T33 & M & $\mathrm{p}$ diff. ser. adenocarcinoma & III & I & I & I & I \\
\hline T35 & M & $\mathrm{p}$ diff. ser. adenocarcinoma & III & 1 & 1 & 1 & 1 \\
\hline T18 & M & Undiff. adenocarcinoma & III & W,I & W,I & W,I & W,I \\
\hline T28 & M & undiff. adenocarcinoma & I & 1 & I & I & 1 \\
\hline
\end{tabular}

Abbreviations: W, Western blotting performed; I, immunohistochemistry performed; N, normal; B, benign; BL, borderline; $\mathrm{M}$, malignant; $\mathrm{h}$, highly; $\mathrm{m}$, moderately; $p$, poorly; diff, differentiated; ser, serous; muc, mucinous.

We have studied the expression of four of the members of the C/EBP family members $(\mathrm{C} / \mathrm{EBP} \alpha,-\beta,-\delta,-\zeta)$ in tissue specimens of ovarian epithelial tumours of different grades and stages in order to elucidate possible roles of these transcription factors in tumour formation in vivo. The specimens were analysed for cell-specific localization by immunohistochemistry and further quantified by Western blotting.

\section{MATERIALS AND METHODS}

\section{Human tissues}

Biopsies from normal ovaries and tumour tissues of ovarian origin were obtained from 35 patients undergoing laparotomy (approved by the Ethics Committee of the Medical Faculty, Göteborg University). The material is described in Table 1. Tissues were immediately washed in ice-cold $0.9 \%$ sodium chloride, snapfrozen in liquid nitrogen and stored at $-70^{\circ} \mathrm{C}$ until analysis. All samples were examined by two independent and experienced pathologists for diagnosis.

\section{Primary antibodies}

The following antibodies/antiserum were used: $\mathrm{C} / \mathrm{EBP} \alpha$ (rabbit polyclonal, cat. no. sc-61 and a rabbit antiserum provided by SL
McKnight, Dallas, TX, USA), C/EBP (rabbit polyclonal, cat. no. sc-150), C/EBP $\delta$ (rabbit polyclonal, cat. no. sc-151), $\mathrm{C} / \mathrm{EBP} \zeta$ (GADD153) (rabbit polyclonal, cat. no. sc-793) and proliferating cell nuclear antigen (PCNA, mouse monoclonal, cat. no. sc-56). All antibodies were from Santa Cruz Biotechnology (San Diego, $\mathrm{CA}$, USA). The antiserum against $\mathrm{C} / \mathrm{EBP} \alpha$ was used for immunohistochemistry (Piontkewitz et al, 1993). All C/EBP antibodies were diluted 1:500 for Western blotting and 1:100 for immunohistochemistry. The dilution of the PCNA antibody was 1:500. Cytokeratin AE1/AE3 monoclonal antibody was used at a dilution of 1:40 (Cat. no. 1124161, Boehringer Mannheim, Germany).

\section{Immunohistochemistry}

Fresh-frozen tissues were cryosectioned and fixed in cold acetone at $-20^{\circ} \mathrm{C}$ for $10 \mathrm{~min}$, then dried at room temperature. The slides were then hydrated with cold phosphate-buffered saline (PBS) and blocked with $5 \%$ non-fat milk (NFM) for $30 \mathrm{~min}$, before the addition of the primary antibodies diluted in buffer solution [PBS with $1 \%$ bovine serum albumin (BSA), $0.2 \%$ Triton $\mathrm{X}-100,0.1 \%$ sodium azide], and left overnight at room temperature. Bound antibodies were visualized by biotinylated secondary horse antirabbit (C/EBP) or anti-mouse (cytokeratin) antibodies (Vector, Burlingham, CA, USA) and streptavidin-fluorescein isothiocyanate (FITC, Amersham, Buckinghamshire, UK). Sections were mounted with Moviol/Dabco mounting medium (0.4\% Moviol, Hoechst, Frankfurt am Main, Germany) in $30 \%$ glycerol with the addition of 2.5\% Dabco (4-diazabicyclo (2.2.2) octane; Fluka, Buchs, Switzerland) (Piontkewitz et al, 1993). In the control sections, which showed only negligible signals, the first antibody was replaced by 5\% NFM (data not shown). The sections were viewed and photographed with a Nikon microphot FX fluorescence microscope. All sections were stained with an antibody against cytokeratin to verify the epithelial origin of cells.

\section{Western blotting}

Soluble tissues were prepared by homogenization in a PE buffer (10 mm potassium phosphate buffer, $\mathrm{pH} 6.8$, and $1 \mathrm{~mm}$ EDTA) containing $10 \mathrm{mM}$ 3-(3-cholamidopropyl)dimethyl-ammonio 1-propane sulphate (CHAPS), aprotinin (200 kallikrein inhibitory units per ml), leupeptin $\left(1 \mathrm{mg} \mathrm{ml}^{-1}\right)$, pepstatin $\left(1 \mathrm{mg} \mathrm{ml}^{-1}\right)$ and Pefablock ${ }^{\circledR}\left(1 \mathrm{mg} \mathrm{ml}^{-1}\right)$ (Boehringer Mannheim, Germany). The homogenate was then sonicated (twice, for $15 \mathrm{~s}$ each time) and centrifuged $\left(10000 \mathrm{~g}, 10 \mathrm{~min}, 4^{\circ} \mathrm{C}\right)$. Supernatants were stored at $-70^{\circ} \mathrm{C}$ until analysis. The protein concentrations were measured according to Lowry. The samples were diluted in sodium dodecyl sulphate (SDS) sample buffer and heated at $95^{\circ} \mathrm{C}$ for $5 \mathrm{~min}$ before loading on a SDS-polyacrylamide gel (12\% Tris-glycine) (NOVEX, San Diego, CA, USA). Fifty micrograms of total protein was loaded into each lane. The proteins were transferred to a polyvinyldifluoride membrane (Amersham, Buckinghamshire, UK) using a blotting system (NOVEX). The membrane was then incubated with specific antibodies. Prestained standards (SeeBlue, NOVEX) were used as weight markers. Immunoreactive protein was visualized by chemiluminescence using alkaline phosphataseconjugated secondary goat anti-rabbit antibodies (dilution: 1:20 000) or goat anti-mouse antibodies (dilution 1:10 000) (Santa Cruz Biotechnology), and CSPD or CDP Star (Tropix, Bedford, MA, USA) as substrate. The membrane was exposed to ECL film 
(Amersham, Buckinghamshire, UK) at room temperature. For semiquantitative measurement of proteins on these Western blots, a software package (Quantity One, PDI, NY, USA) in The Discovery Series Densitometric Systems (Pharmacia Biotech, Lund, Sweden) with Desk Top Plus Scanner, were used. The optical density $(\mathrm{OD}) \times \mathrm{mm}$ from each band was measured.

Statistical difference was evaluated by $t$-test (two sample) and a value of $P<0.05$ was considered to be significant (Altman, 1991).

\section{RESULTS}

\section{$\mathrm{C} / \mathrm{EBP} \alpha$}

The immunohistochemical analyses included 23 samples (Table 1). $\mathrm{C} / \mathrm{EBP} \alpha$ was detected mainly as a cytoplasmic staining in all of the tumours and also in the normal ovaries. Nuclear staining was only apparent in adipose cells adjacent to the tumour tissue (Figure 1C). The expression was restricted to epithelial cells in most of the samples (Figure 2A, D), and staining of the stroma cells was demonstrated in only two of the samples (T31 and T52). CEBP $\alpha$ was also expressed in the epithelial cell layers of inclusion cysts (N5 and T12). The intensity of the staining was rather constant in the different tumour samples and did not appear to be related to stage or grade of the tumour.

The Western blotting analyses of C/EBP $\alpha$ included 17 samples (Table 1). The expression of $\mathrm{C} / \mathrm{EBP} \alpha$ was constant in all samples, with a slightly lower content in the undifferentiated tumour (Figure 5B). In addition to the expected band with a molecular weight of $42 \mathrm{kDa}$, a band of $30 \mathrm{kDa}$ was detected in all samples, except in the undifferentiated tumour. This band represents a shorter form of the protein, lacking a part of its activating region (Lin et al, 1993). A constant band of approximately $50 \mathrm{kDa}$ was also noted in all samples. This signal $[\mathrm{C} / \mathrm{EBP}$ reactive material (CRM, Cao et al, 1991)] was unrelated to normal or tumour tissues. This band was also present in other cell types and species (data not shown).

\section{C/EBP $\beta$}

In the normal ovary, the OSE cells at the ovarian surface expressed minute amounts of $\mathrm{C} / \mathrm{EBP} \beta$, whereas epithelial cells of cleft formations and inclusion cysts were positively stained (Figure 3). An intense staining was demonstrated in all tumours and the expression of C/EBP $\beta$ was restricted to the epithelial cells, regardless of the tumour type. Stromal staining was demonstrated in only four samples (T29, T31, T32 and T52), and this signal was less intense than in the epithelial cells. $\mathrm{C} / \mathrm{EBP} \beta$ expression was more pronounced in the malignant samples, although it was detected at all stages of dedifferentiation and in all grades (Figure 4). Furthermore, the immunohistochemical analyses of 22 samples (Table 1) revealed a different intracellular distribution of $\mathrm{C} / \mathrm{EBP} \beta$ compared with that of $\mathrm{C} / \mathrm{EBP} \alpha$. $\mathrm{C} / \mathrm{EBP} \beta$ was localized to the nucleus in the majority of tumour cells in the malignant samples (Figures 1D, 4), in contrast to $\mathrm{C} / \mathrm{EBP} \alpha$, which demonstrated mainly a cytoplasmic staining. In the inclusion cysts (N5 and $\mathrm{T} 12$ ), both cytoplasmic and nuclear staining was observed for C/EBP 3 (Figure 3B).

The presence of $\mathrm{C} / \mathrm{EBP} \beta$ was investigated by Western blotting in 14 samples (Table 1). The intact, full-length protein was detected as two bands, at $34 \mathrm{kDa}$ and $38 \mathrm{kDa}$. The two normal ovaries expressed $\mathrm{C} / \mathrm{EBP} \beta$, while the benign and borderline samples contained minute amounts of the protein. All the malignant samples contained large amounts of C/EBP $\beta$ (Figure 5A). In fact, the expression in the malignant samples was significantly higher $(P<0.01)$ than in normal ovaries and benign/borderline tumours. In addition, the malignant tumours contained a band at $18 \mathrm{kDa}$, representing the shorter form of the protein, LIP (Descombes and Scibler, 1991). The pattern of expression of $\mathrm{C} / \mathrm{EBP} \beta$ with an increased content in the malignant tumours correlated with that of PCNA (Figure 6).

\section{C/EBP $\delta$}

Immunohistochemical analyses of 23 tissue sections (Table 1) for $\mathrm{C} / \mathrm{EBP} \delta$ revealed staining of epithelial cells, while stromal staining was detected in 13 of these tumours $(56 \%)$. In some of the sections, the stromal signals appeared as dots (Figure 2B, E). $\mathrm{C} / \mathrm{EBP} \delta$ was detected in the nucleus in all samples (Figures $1 \mathrm{E}$ and $2 \mathrm{~B}, \mathrm{E})$. The intensity of the staining was constant, although some malignant tumours exhibited a stronger signal.

The contents of $\mathrm{C} / \mathrm{EBP} \delta$ were analysed in 13 samples with Western blotting (Table 1). The band of $30 \mathrm{kDa}$ representing this protein was present in all samples. The levels were variable and no pattern related to degree of differentiation or grade could be detected. The malignant tumours expressed an additional band of $36 \mathrm{kDa}$ (Figure 5B).

\section{C/EBP $\zeta$}

Immunohistochemical analyses included 22 samples (Table 1). The staining was predominantly localized to the epithelial areas of the tumours, although seven of the samples (32\%) also demonstrated $\mathrm{C} / \mathrm{EBP} \zeta$ signals in the stromal tissue (Figures $1 \mathrm{~F}$ and $2 \mathrm{C}$, F). A faint staining was also demonstrated in the epithelial cells of inclusion cysts. The intracellular localization of $\mathrm{C} / \mathrm{EBP} \zeta$ was predominantly perinuclear in both epithelial and stromal cells. These signals sometimes appeared as rings or dashes (data not shown).

Western blotting of 17 samples (Table 1) demonstrated C/EBP $\zeta$ as a $29-\mathrm{kDa}$ band. The expression was slightly higher in the malignant tumours than in normal ovaries and benign tumours, although the difference was not as pronounced as for C/EBP $\beta$. In addition, a band of approximately $20 \mathrm{kDa}$ was visible in the malignant tumours (Figure 5B).

\section{DISCUSSION}

We have investigated the presence of four members of the C/EBP family in epithelial ovarian tumours and normal ovaries. In this study, we found that the expression of $\mathrm{C} / \mathrm{EBP} \beta$ was more pronounced in malignant tumours than in benign and borderline tumours. These differences in the contents were correlated with the expression of PCNA, a marker for cell proliferation (Takasaki et al, 1981), in the same samples. As C/EBP $\beta$ is known to be expressed in cells in vitro at proliferative and not fully differentiated stages, this finding also suggests a role for $\mathrm{C} / \mathrm{EBP} \beta$ during increased proliferation of tumour cells, similar to the proposed function of classical oncogenes and transcription factors in tumorigenesis.

The C/EBP $\beta$ protein was detected as two bands of the fulllength protein (LAP) at $34 \mathrm{kDa}$ and $38 \mathrm{kDa}$. Multiple forms of 

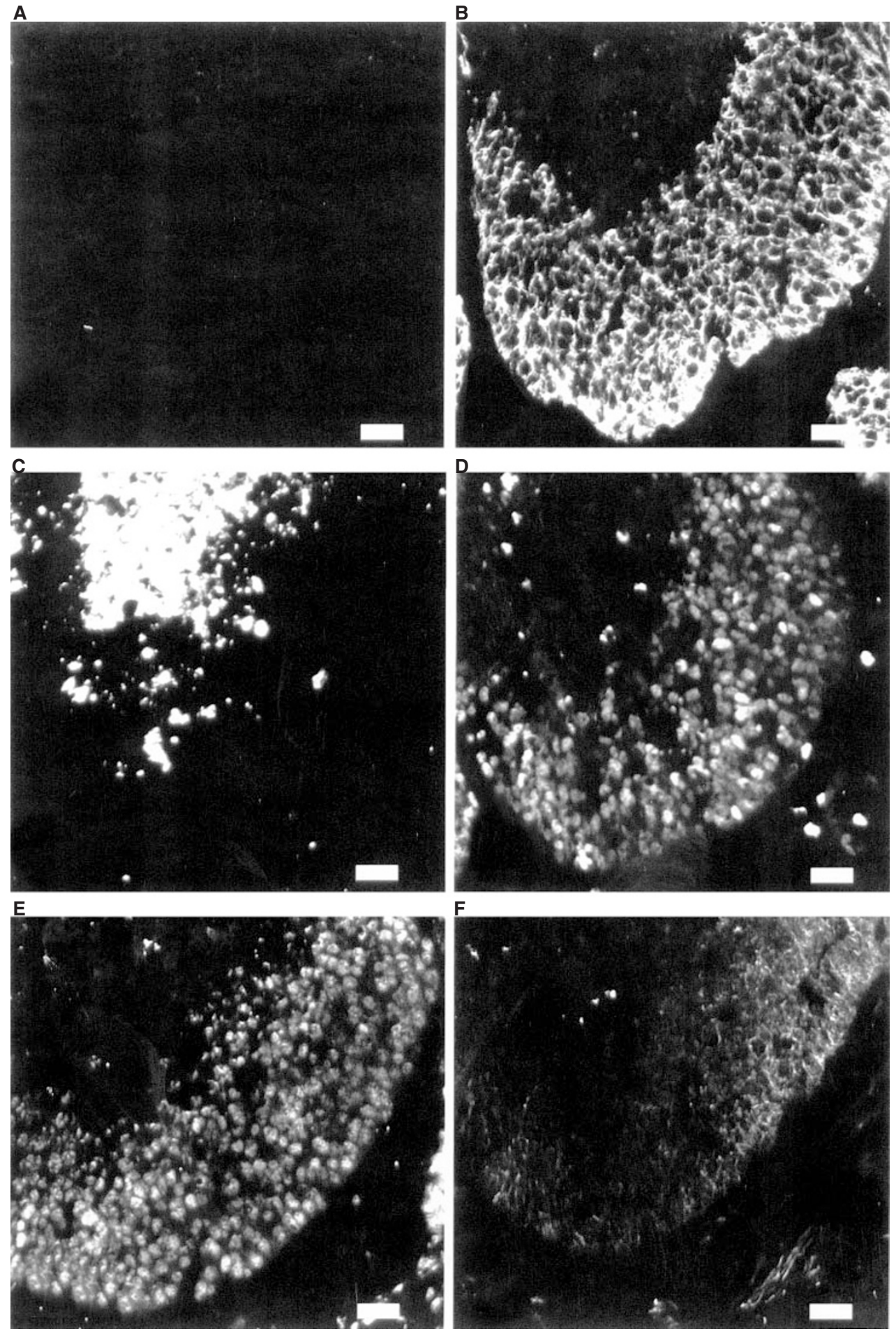

Figure 1 Detection of four members of the C/EBP family with immunohistochemistry in a moderately differentiated serous adenocarcinoma (T31) (bar $=50 \mu \mathrm{m}$ ). (A) Negative control, (B) cytokeratin as a marker of epithelial cells, (C) C/EBP $\alpha,(D) C / E B P \beta,(E) C / E B P \delta$ and (F) C/EBP $\zeta$

LAP (30-40 kDa) were demonstrated in mouse mammary epithelial cells (Raught et al, 1995). The appearance of such forms might be attributed to post-translational modifications, e.g. phosphorylations. In fact, $\mathrm{C} / \mathrm{EBP} \beta$ was demonstrated to be phosphorylated by cyclic AMP-dependent protein kinase in vitro (Park et al, 1993) and $\mathrm{Ca}^{2+}$ calmodulin-dependent protein kinases in vitro (Wegner et $\mathrm{al}, 1992$ ). The shorter form of C/EBP $\beta$ (LIP, $18 \mathrm{kDa}$ ) was detected only in the malignant samples, although this does not exclude the presence of small amounts of the proteins in the normal ovary and in the benign tumours. The two isoforms, LAP and LIP, are explained by differential use of two AUGs within the same transcript (Descombes and Schibler, 1991). LIP is probably not functional as an activator of transcription, because the activational domain in the $\mathrm{N}$-terminal part of the protein is missing. More 

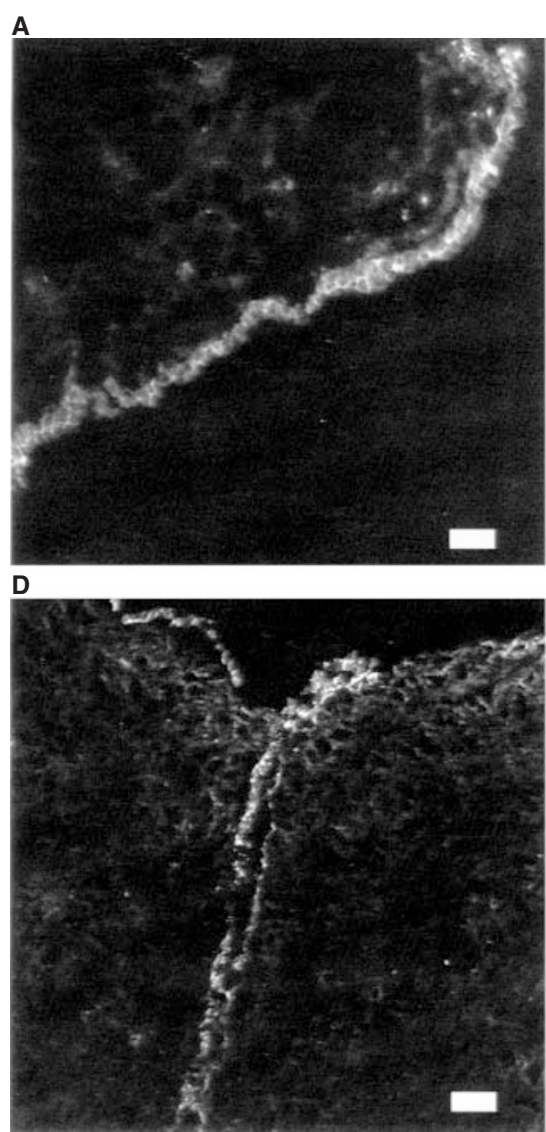

B
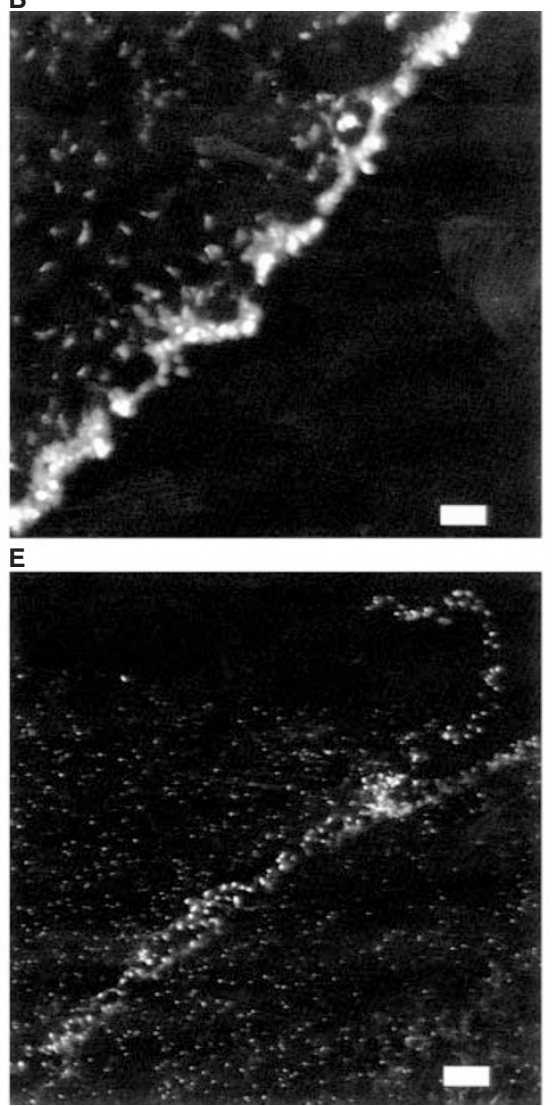
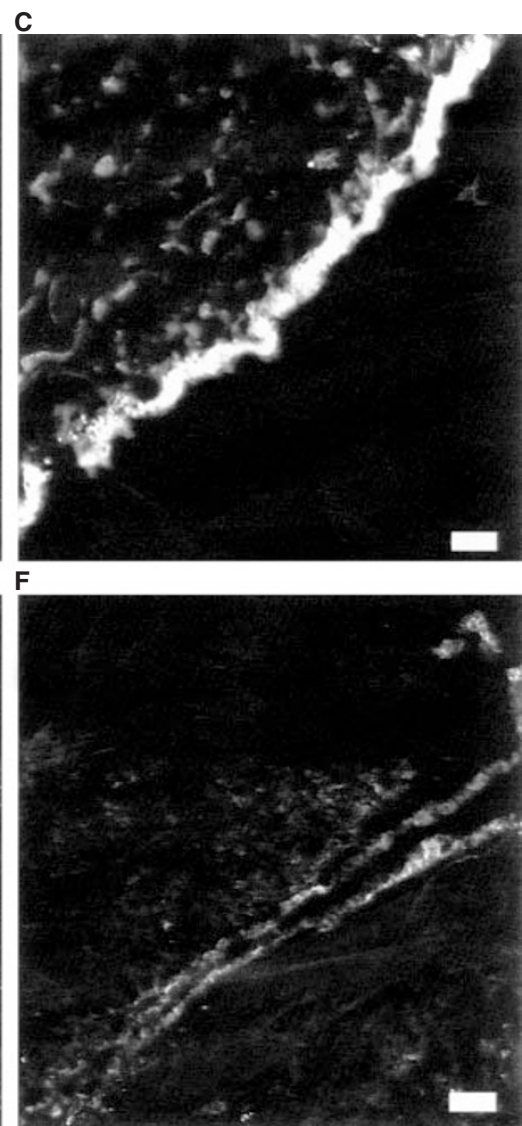

Figure 2 Detection with immunohistochemistry (bar $=50 \mu \mathrm{m})$ of $\mathrm{C} / \mathrm{EBP} \alpha(\mathbf{A}$ and $\mathbf{D}), \mathrm{C} / \mathrm{EBP} \delta(\mathbf{B}$ and $\mathbf{E})$ and $\mathrm{C} / \mathrm{EBP} \zeta(\mathbf{C}$ and $\mathbf{F})$, in a post-menopausal normal ovary (N5); surface epithelium (A-C), epithelial cells lining a cleft formation (D-F)
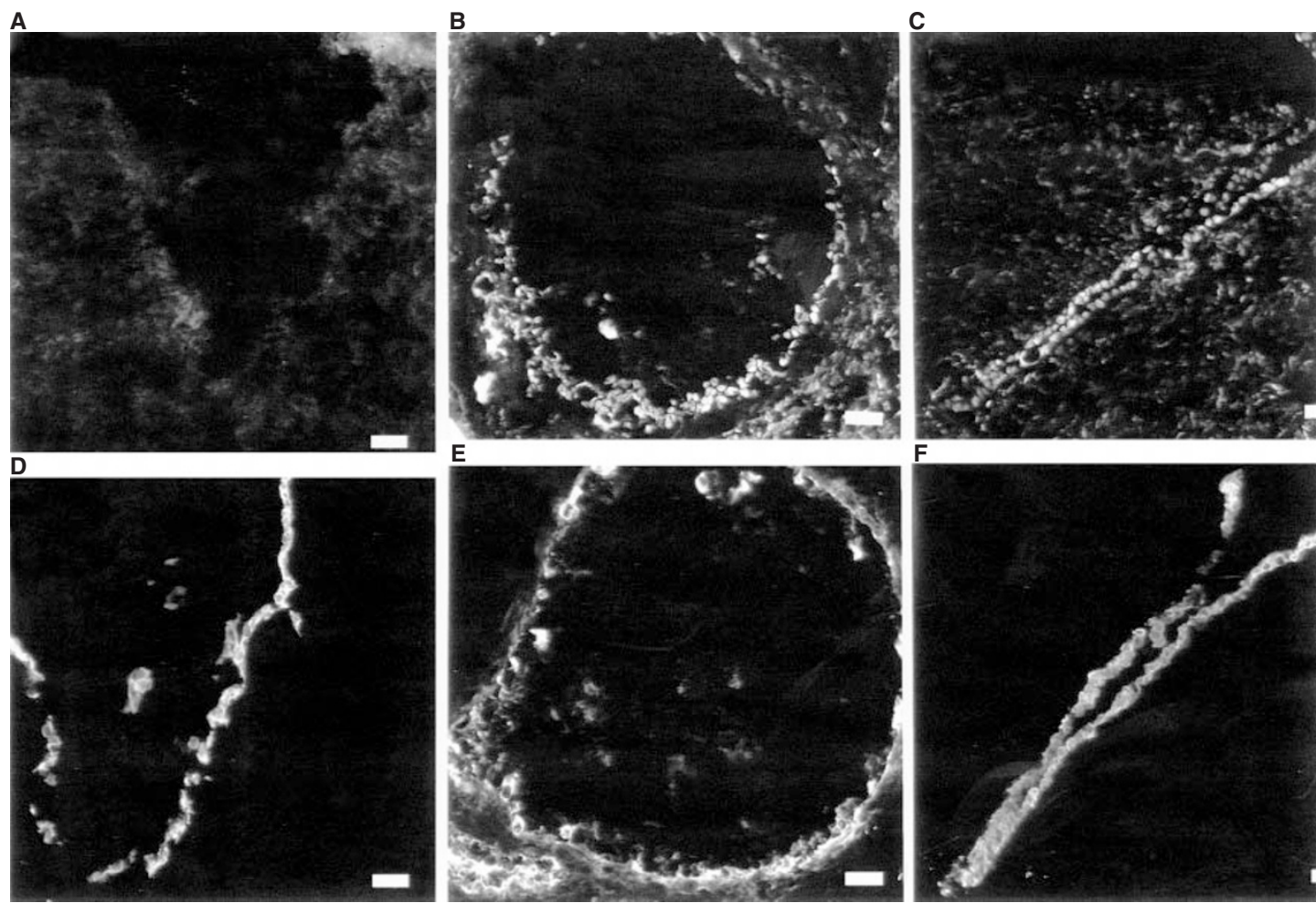

Figure 3 Detection of C/EBP $\beta$ in a post-menopausal normal ovary (N5) with immunohistochemistry $(b a r=50 \mu m)(A)$ surface epithelial cells, (B) inclusion cyst, (C) cleft formation and (D-F) corresponding tissue sections incubated with antibodies against cytokeratin, a marker of epithelial cells 
A
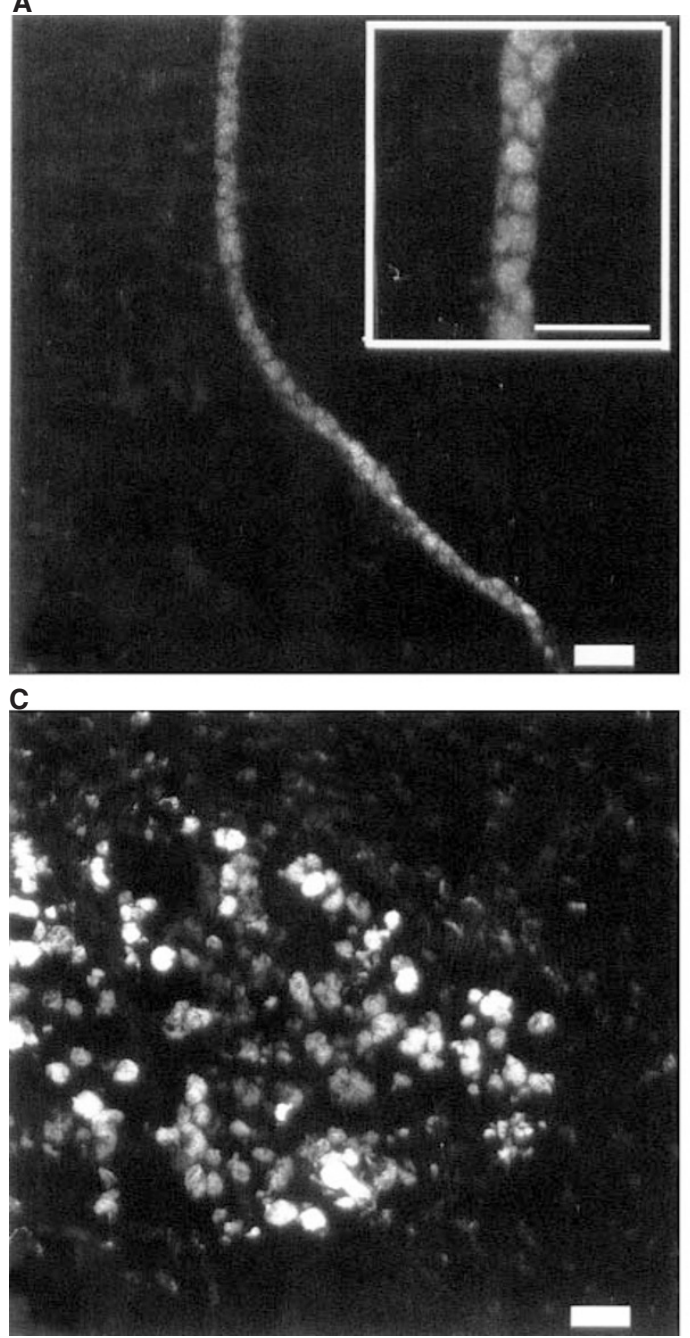

B
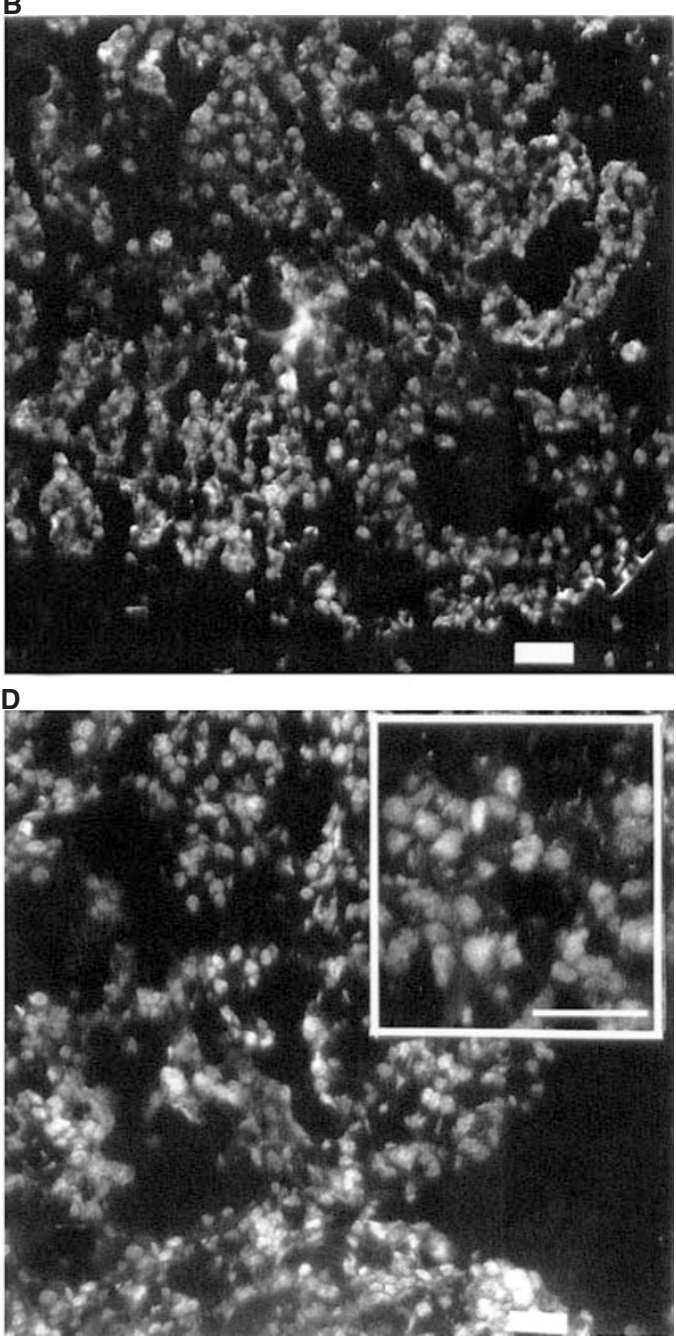

Figure 4 Detection of C/EBP $\beta$ in (A) epithelial cells of a borderline tumour (T16), (B) moderately differentiated adenocarcinoma (T30), (C) poorly differentiated adenocarcinoma (T33) and (D) undifferentiated adenocarcinoma (T18) (bar $=50 \mu \mathrm{m})$

likely, the shorter form represses the functions of $\mathrm{C} / \mathrm{EBP} \beta$ by the formation of inactive dimers with the full-length protein. The ratio between the two different forms of the C/EBP $\beta$ was suggested to be of importance for the transcriptional activity in mouse mammary epithelial cells (Raught et al, 1995).

The immunohistochemical analyses revealed that the increased expression of $\mathrm{C} / \mathrm{EBP} \beta$ was preferentially localized to epithelial cells within the tumours. However, invaginated OSE cells in cleft formations and epithelial cells lining cysts also stained positive for $\mathrm{C} / \mathrm{EBP} \beta$. The stromal compartments of normal ovaries and of tumours stained negative almost without exception. The specific appearance of C/EBP $\beta$ in inclusion cyst is of interest for the pathogenesis of epithelial ovarian tumours since such cysts have been suggested to constitute the initial steps in tumour development (Hamilton, 1992). The present results suggest a putative role for $\mathrm{C} / \mathrm{EBP} \beta$ in the initial, proliferative process but also later in tumorigenesis of these cells in vivo. The low contents of C/EBP $\beta$ in benign tumours may indicate that these tumours represent a different trait in tumour formation without the potential of malignant transformation, or that their growth capacity is very low.
$\mathrm{C} / \mathrm{EBP} \beta$ was present in the nucleus of the epithelial cells in all samples. This was in contrast to $\mathrm{C} / \mathrm{EBP} \alpha$ which was mainly localized to the cytoplasm. The localization of $\mathrm{C} / \mathrm{EBP} \beta$ to the nucleus, together with the increased levels of this protein, proposes an active involvement in the transcriptional machinery of these cells. However, cytoplasmic localization of transcription factors, as noted for $\mathrm{C} / \mathrm{EBP} \alpha$, may also reflect a regulatory pathway to inhibit transcriptional activity. For example, the activity of the transcription factor $\mathrm{NFKB}$, is mainly regulated by shuttling of the protein between cytoplasm and nucleus (Ghosh and Baltimore, 1990). Such extranuclear localization of $\mathrm{C} / \mathrm{EBP} \alpha$ in malignant cells suggests an 'inactive' state of this transcription factor. In fact, translocation of $\mathrm{C} / \mathrm{EBP} \alpha, \mathrm{C} / \mathrm{EBP} \beta$ and $\mathrm{C} / \mathrm{EBP} \delta$ between the cytoplasm and nucleus was regulated by tumour necrosis factor $\alpha$ (TNF- $\alpha$ ) in hepatocytes in vitro (Yin et al, 1996). Interestingly, the expression of TNF- $\alpha$ in ovarian tumours was demonstrated to be positively correlated with tumour grade (Naylor et al, 1993). TNF$\alpha$ has also been described as a growth factor for the ovarian tumour cells (Wu et al, 1993). These observations indicate that TNF- $\alpha$ could be involved in the post-translational regulation of $\mathrm{C} / \mathrm{EBP}$ 

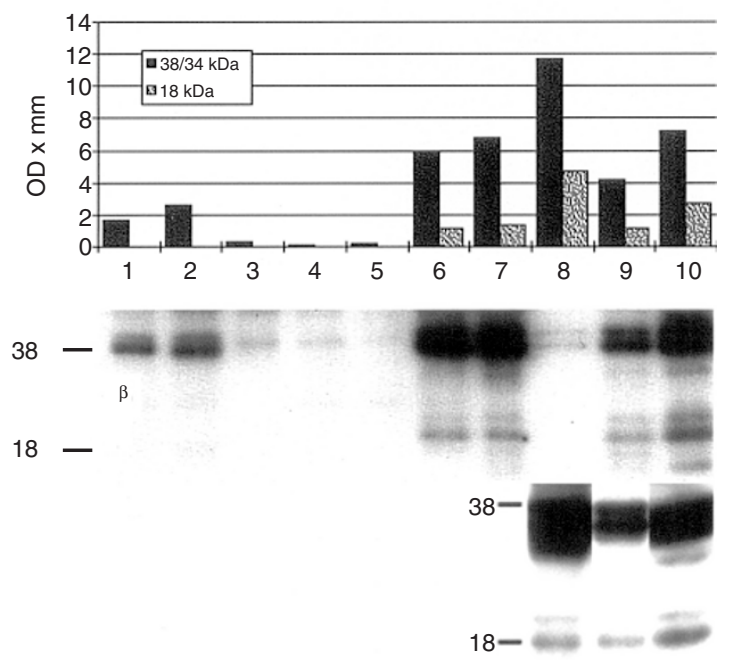

B
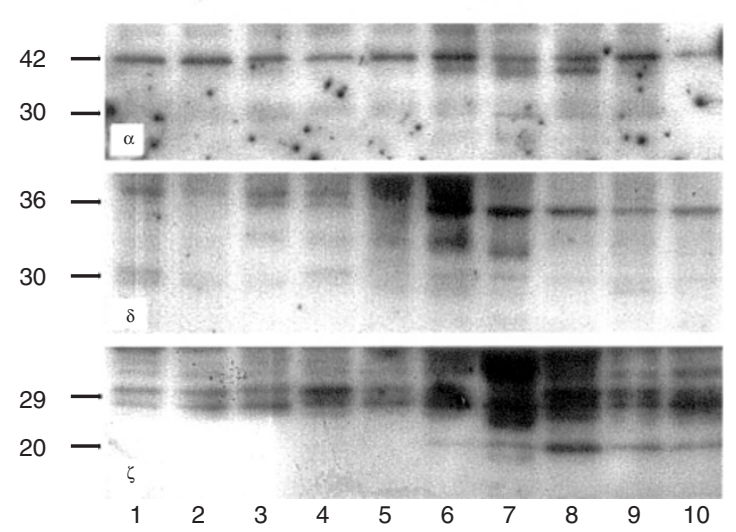

Figure 5 Western blotting analysis of four members of the C/EBP family. (A) C/EBP (LAP 34 and $38 \mathrm{kDa}$, LIP $18 \mathrm{kDa}$ ) and the quantification by densitometry (OD $\times \mathrm{mm}$, the result of sample 8 refers to lower blot). (B) $\mathrm{C} / \mathrm{EBP} \alpha(42 \mathrm{kDa}), \mathrm{C} / \mathrm{EBP} \delta(30 \mathrm{kDa})$ and $\mathrm{C} / \mathrm{EBP} \zeta(29 \mathrm{kDa})$. The samples: 1 and 2, normal post menopausal ovaries (N1, N4); 3 and 4, benign tumours (T12, T8); 5 , a borderline tumour (T5); 6-9, medium to poorly differentiated malignant tumours (T11, T9, T10a, T14); and 10, undifferentiated malignant tumour (T18)

proteins in ovarian tumour cells. Studies have also revealed that the relocalization and transition of C/EBP into a nuclear, activated state was dependent on phosphorylation, mediated by cyclic AMPdependent or $\mathrm{Ca}^{2+}$-dependent protein kinases (Metz and Ziff, 1991).

$\mathrm{C} / \mathrm{EBP} \beta$ has mainly been found to induce expression of genes in acute-phase responses (Akira et al, 1990; Poli et al, 1990), such as granulocyte colony-stimulating factor (G-CSF) (Tanaka et al, 1995), interleukin (IL)-6 (Poli et al, 1990), and IL-8 (Matsusaka et al, 1993). Interestingly, IL-6 was expressed at high levels in ovarian tumours and stimulated proliferation of these cells (Watson et al, 1993). IL-8 was also measured in ovarian tumours, and the concentration of the protein was markedly higher in cyst fluid from malignant compared to benign tumours (Ivarsson et al, 1997). Both these cytokines, IL-6 and IL-8, were regulated by C/EBP $\beta$ in synergy with NFKB (Matsusaka et al, 1993). Furthermore, the expression of $\mathrm{C} / \mathrm{EBP} \beta$ could be stimulated by inflammatory substances, e.g.

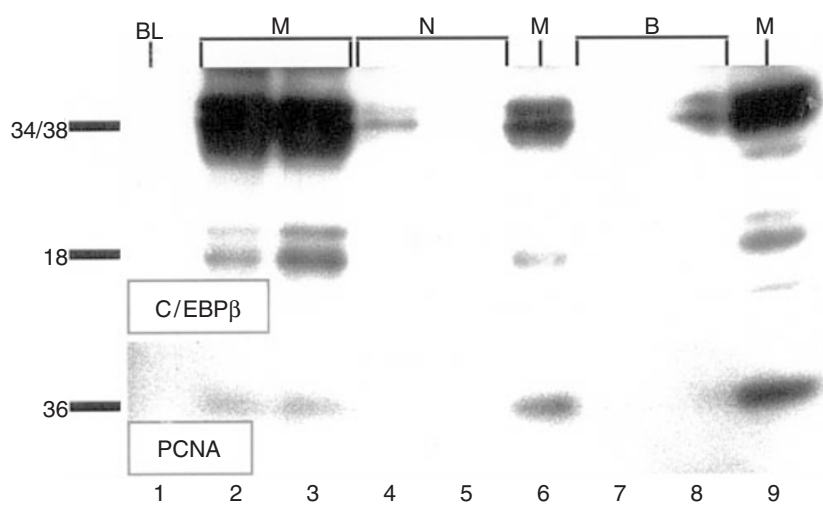

Figure 6 Comparison of Western blots for C/EBP $\beta$ (LAP, 34/38 kDa and LIP, $18 \mathrm{kDa}$ ) (top) and PCNA (36 kDa) (bottom). The samples: 1, T5; 2, T10a; 3, T10b; 4, N1; 5, N2; 6, T14; 7, T16; 8, T17; 9, T18. Abbreviations: $\mathrm{N}$, normal ovary; $\mathrm{B}$, benign tumour; $\mathrm{BL}$, borderline tumour; $\mathrm{M}$, malignant tumour

lipopolysacharides (LPS), IL-1 and IL-6 (Akira and Kishimoto, 1992). Recently, C/EBP $\beta$ was connected with proteins involved in the cell cycle, e.g. the tumour-suppressor retinoblastoma protein, $\mathrm{Rb}$. $\mathrm{Rb}$ was demonstrated to directly interact and activate $\mathrm{C} / \mathrm{EBP} \beta$ (Chen et al, 1996). Loss or altered expression of Rb was suggested to be a primary event in many malignancies and this might also influence the activity of C/EBP $\beta$. Studies in primary ovarian carcinomas demonstrated that $\mathrm{Rb}$ was normally expressed in a majority of these tumours (Dodson et al, 1994). Therefore, a direct interaction between $\mathrm{Rb}$ and $\mathrm{C} / \mathrm{EBP} \beta$ is plausible in epithelial ovarian tumour cells and suggests a role for $\mathrm{C} / \mathrm{EBP} \beta$ in the control of the cell cycle. In fact, a direct, cell cycle-regulated DNA-binding activity of $\mathrm{C} / \mathrm{EBP} \beta$ was demonstrated in regenerating rat hepatocytes in vivo (Rana et al, 1995).

Recently, the expression of the C/EBP $\beta$ isoforms (LAP and LIP) was examined in human breast tumours (Zahnow et al, 1997). It was found that LIP was present in malignant tumours, which stained negative for steroid receptors, suggesting that LIP might be useful as a prognostic marker for the identification of patients with a poor prognosis. $\mathrm{C} / \mathrm{EBP} \alpha$ was examined in liver carcinomas $(\mathrm{Xu}$ et al, 1994), where it was localized to both the nucleus and cytoplasm of the tumour cells. The expression of the protein was decreased when these tumours dedifferentiated. The anti-proliferating and anti-tumour properties of $\mathrm{C} / \mathrm{EBP} \alpha$ were demonstrated by induction of $\mathrm{C} / \mathrm{EBP} \alpha$ in human tumour cell lines (Timchenko et al, 1996; Watkins et al, 1996). This induction was mediated by increased levels of the cell cycle protein p21 (WAF-1), which is also regulated by the tumour suppressor $\mathrm{p} 53$.

In addition to the interaction with other factors for the transcriptional regulation of genes, the C/EBP proteins themselves affect the function of each other in a complex manner. The different members form both homo- and heterodimers, thereby extending and altering their regulatory potential. One of the proteins, $\mathrm{C} / \mathrm{EBP} \zeta$, has a different DNA-binding domain from the other members. Two amino acids in the basic region are replaced by prolines, which makes them unable to recognize the classic CCAAT sites. $\mathrm{C} / \mathrm{EBP} \zeta$ can therefore act as a potent inhibitor of the other factors, directing them away from their target DNA (Ron and Habener, 1992). C/EBP $\zeta$ was induced by cellular stress and inhibited proliferation with a subsequent arrest of growth in the $G_{1} / S$ checkpoint. A fusion protein, TLS-CHOP, which inhibited the 
normal function of $\mathrm{C} / \mathrm{EBP} \zeta(\mathrm{CHOP})$ was demonstrated in myxoid liposarcoma (Aman et al, 1992). The effect of $\mathrm{C} / \mathrm{EBP} \zeta$ in differentiation was further investigated in 3T3-L1 cells that failed to convert into adipocytes. This effect was mediated by a reduction in $\mathrm{C} / \mathrm{EBP} \alpha$ gene expression (Batchvarova et al, 1995). In the present study, there was a minor increase in the concentration of $\mathrm{C} / \mathrm{EBP} \zeta$ in the more malignant samples. As the immunohistochemical experiments revealed that most of the protein was localized outside the nucleus, this factor may exert some of its inhibitory potential in the cytoplasm, e.g. by binding to other leucine-zipper proteins and thereby blocking their entrance into the nucleus. An additional band of approximately $35 \mathrm{kDa}$ was observed for $\mathrm{C} / \mathrm{EBP} \delta$ in the malignant tumours. Such a band might be attributable to extensive phosphorylation resulting in an altered function of the transcription factor (Park et al, 1993; Wegner et al, 1992). However, further studies are needed to reveal the pattern of phosphorylation of the different C/EBP proteins in tumour cells and to examine the effect of such modifications on their transcriptional activities.

In conclusion, the cell- and stage-specific pattern of expression of C/EBPs in epithelial ovarian tumours suggests an involvement of these transcription factors in tumour progression. Further studies are needed to determine their specific actions in the transcriptional machinery during dedifferentiation and proliferation of tumour cells. Thus, this family of transcription factors has the potential to be the target for both diagnostic and therapeutic development.

\section{ACKNOWLEDGEMENTS}

This study was supported by the Swedish Medical Research Council (10375 and 12605 to LH), the Foundations of Magnus Bergvall, Ollie and Elof Ericsson, Assar Gabrielsson, Göteborg Medical Society, Hjalmar Svensson, Lundberg and King Gustav V Jubilee Clinic Cancer Research.

\section{REFERENCES}

Akira S, Isshiki H, Sugita T, Tanabe O, Kinoshita S, Nishio Y, Nakajima T, Hirano T and Kishimoto T (1990) A nuclear factor for IL-6 expression (NF-IL6) is a member of a C/EBP family. EMBO J 9: 1897-1906

Akira S and Kishimoto T (1992) IL-6 and NF-IL6 in acute-phase response and viral infection. Immunol Rev 127: 25-50

Altman DG (1991) Practical Statistics for Medical Research. Chapman and Hall: London

Aman P, Ron D, Mandahl N, Fioretos T, Heim S, Arheden K, Willén H, Rydholm A and Mitelman F (1992) Rearrangement of the transcription factor gene CHOP in myxoid liposarcomas With t(12;16)(q13;p11). Gene Chrom Cancer 5 $278-285$

Batchvarova N, Wang X-Z and Ron D (1995) Inhibition of adipogenesis by the stress-induced protein CHOP (Gadd 153). EMBO J 14: 4654-4661

Cao Z, Umek RM and McKnight SL (1991) Regulated expression of three C/EBP isoforms during adipose conversion of 3T3-L1 cells. Genes Dev 5: 1538-1552

Chandrasekaran C and Gordon JI (1993) Cell lineage-specific and differentiationdependent patterns of CCAAT/enhancer binding protein $\alpha$ expression in the gut epithelium of normal and transgenic mice. Proc Natl Acad Sci USA 90: $8871-8875$

Chen PL, Riley DJ, Chen-Kiang S and Lee WH (1996) Retinoblastoma protein directly interacts with and activates the transcription factor NF-IL6. Proc Natl Acad Sci USA 93: 465-469

Descombes P and Schibler U (1991) A liver-enriched transcriptional activator protein, LAP, and a transcriptional inhibitory protein, LIP, are translated from the same mRNA. Cell 67: 569-579

Dodson MK, Cliby WA, Xu HJ, DeLacey KA, Hu SX, Keeney GL, Li J, Podratz KC, Jenkins RB and Benedict WF (1994) Evidence of functional RB protein in epithelial ovarian carcinomas despite loss of heterozygosity at the RB locus. Cancer Res 54: 610-603
Ghosh S and Baltimore D (1990) Activation in vitro of NF Kappa B by phosphorylation of its inhibitor I kappa B. Nature 344: 678-682

Hamilton TC (1992) Ovarian Cancer, part 1: Biology. In Curr Prob Cancer 16: 1-57 Ivarsson KU, Runesson EB, Haeger M, Sundfeldt K, Hedin LF, Janson PO and Brännström M (1999) The chemotactic cytokine interleukin-8 (IL-8) a cyst fluid marker for malignant human epithelial ovarian cancer. Gynecol Oncol (in press)

Li F, Rosenberg E, Smith CI, Notarfrancesco K, Reisher SR, Shuman H and Feinstein SI (1995) Correlation of expression of transcription factor C/EBP- $\alpha$ and surfactant protein genes in lung cells. Am J Physiol 269: L241-L247

Lin F-T, MacDougald OA, Diehl AM and Lane MD (1993) A 30-kDa alternative translation product of the CCAAT/enhancer binding protein $\alpha$ message: transcriptional activator lacking antimitotic activity. Proc Natl Acad Sci USA 90: 9606-9610

Matsusaka T, Fujikawa K, Nishio Y, Mukaida N, Matsashima K, Kishimoto T and Akira S (1993) Transcription factors NF-IL6 and NF-kB synergistically activate transcription of the inflammatory cytokines, interleukin 6 and interleukin 8. Proc Natl Acad Sci USA 90: 10193-10197

McKnight SL (1991) C/EBP: A transcription factor that promotes terminal cell differentiation in a wide spectrum of tissues. In Origins of Human Cancer: $a$ Comprehensive Review, Brugge J, Curran T, Harlow E and McCormick F (eds) pp. 345-352. Cold Spring Harbor Laboratory Press: Cold Spring Harbor

Metz E and Ziff E (1991) cAMP stimulates the C/EBP-related transcription factor rNFIL-6 to translocate to the nucleus and induce c-fos transcription. Genes Dev 5: $1754-1766$

Naylor MS, Stamp GW, Foulkes WD, Eccles D and Balkwill FR (1993) Tumour necrosis factor and its receptors in human ovarian cancer. Potential role in disease progression. J Clin Invest 91: 2194-2206

Park EA, Gurney AL, Nizielski SE, Hakimi P, Cao Z, Moorman A and Hanson RW (1993) Relative roles of CCAAT/enhancer-binding protein beta and cAMP regulatory element-binding protein in controlling transcription of the gene for phosphoenolpyruvate carboxykinase (GTP). J Biol Chem 268: 613-609

Piontkewitz Y, Enerbäck S and Hedin L (1993) Expression and hormonal regulation of the CCAAT enhancer binding protein- $\alpha$ during differentiation of rat ovarian follicles. Endocrinology 133: 2327-2333

Poli V, Mancini FP and Cortese R (1990) IL-6DBP, a nuclear protein involved in interleukin-6 signal transduction, defines a new family of leucine zipper proteins related to C/EBP. Cell 63: 643-653

Rana B, Xie Y, Mischoulon D, Bucher NL and Farmer SR (1995) The DNA binding activity of C/EBP transcription factor is regulated in the G1 phase of the hepatocyte cell cycle. $J$ Biol Chem 270: 18123-18132

Raught B, Liao WS-L and Rosen JM (1995) Developmentally and hormonally regulated CCAAT/enhancer-binding protein isoforms influence $\beta$-casein gene expression. Mol Endocrinology 9: 1223-1232

Ron D and Habener JF (1992) CHOP, a novel developmentally regulated nuclear protein that dimerizes with transcription factors C/EBP and LAP and functions as a dominant-negative inhibitor of gene transcription. Genes Dev 6: 439-453

Samuelsson L, Strömberg K, Vikman K, Bjursell G and Enerbäck S (1991) The CCAAT/enhancer binding protein and its role in adipocyte differentiation: evidence for direct involvement in terminal adipocyte development. EMBOJ 10: $3787-3793$

Scott LM, Civin CI, Rorth P and Friedman AD (1992) A novel temporal expression pattern of three $\mathrm{C} / \mathrm{EBP}$ family members in differentiating myelomonocytic cells. Blood 80: 1725-1735

Silverberg E (1984) Cancer Statistics. CA Cancer J Clin 34: 7-23

Takasaki Y, Deng JS and Tan EM (1981) A nuclear antigen associated with cell proliferation and blast transformation. J Exp Med 154: 1899-1909

Tanaka T, Akira S, Yoshida K, Umemoto M, Yoneda Y, Shirafuji N, Fujiwara H, Suematsu S, Yoshida N and Kishimoto T (1995) Targeted disruption of the NFIL6 gene discloses its essential role in bacteria killing and tumour cytotoxicity by macrophages. Cell $\mathbf{8 0}$ : 353-361

Timchenko NA, Wilde M, Nakanishi M, Smith JR and Darlington GJ (1996) CCAAT/enhancer-binding protein alpha (C/EBP- $\alpha)$ inhibits cell proliferation through the p21 (WAF-1/CIP-1/SDI-1) protein. Genes Dev 10: 804-815

Umek RM, Friedman AD and McKnight SL (1991) CCAAT-enhancer binding protein: a component of differentiation switch. Science 251: 288-292

Vinson CR, Hai T and Boyd SM (1993) Dimerization specificity of the leucine zipper-containing bZIP motif on DNA binding: prediction and rational design. Genes Dev 7: 1047-1058

Watkins PJ, Condresay JP, Huber BE, Jacobs SJ and Adams DJ (1996) Impaired proliferation and tumorigenicity induced by CCAAT/ enhancer binding protein. Cancer Res 56: 1063-1067

Watson JM, Berek JS and Martínez-Maza O (1993) Growth inhibition of ovarian cancer cells induced by antisense IL-6 oligonucleotides. Gynecol Oncol 49: 8-15 
Wegner M, Cao Z and Rosenfeld MG (1992) Calcium-regulated phosphorylation within the leucin zipper of C/EBP. Science 256: 370-373

Wu S, Boyer CM, Whitaker RS, Berchuck A, Wiener JR, Weinberg JB and Bast RC (1993) Tumour necrosis factor alpha as an autocrine and paracrine growth factor for ovarian cancer: monokine induction of tumour cell proliferation and tumour necrosis factor alpha expression. Cancer Res 53: 1939-1944

Xu L-X, Sui Y-F, Wang W-L, Liu Y-F and Gu J-R (1994) Immunohistochemical demonstration of CCAAT/Enhancer Binding Protein (C/EBP) in human liver tissues of various origin. Chin Med J 107: 596-599
Yin M, Yang SQ, Lin HZ, Lane MD, Chatterjee S and Diehl AM (1996) Tumour Necrosis Factor $\alpha$ promotes nuclear localization of cytokine-inducible CCAAT/Enhancer Binding Protein isoform in hepatocytes. J Biol Chem 271: 17974-17978

Zahnow CA, Younes P, Laucirica R and Rosen JM (1997) Overexpression of C/EBP-LIP, a naturally occurring, dominant-negative transcription factor, in human breast cancer. JNCI 89: 1887-1891 